\title{
The nematicidal potentiality of some algal extracts and their role in enhancement the tomato defense genes against root knot - nematodes
}

\author{
Rehab Y. Ghareeb ${ }^{1 *}$, Ibrahim A. Adss ${ }^{2}$, Shokry R. Bayoumi ${ }^{2}$ and Deiaa E. El-Habashy ${ }^{3}$
}

\begin{abstract}
The nematicidal effect of three marine algal, Ulva fasciata Delile (UF) (green algae), Corallina mediterranea, Corallina officinalis (red algae), extracts on egg hatching and second-stage juveniles $\left(J_{2}\right)$ mortality of root-knot nematode (Meloidogyne incognita) in vitro compared to the nematicide activity of Oxamyl 24\% SL (5 m//l) was investigated. Results revealed that all treatments at the applied concentrations suppressed the egg hatching in 3 days. In details, the algal strain Ulva fasciata Delile extract showed the highest activity in decreasing the eggs hatchability after 3 days with $87 \%$. Consequently, all treatments significantly increased the mortality of $\mathrm{J}_{2}$ larvae after 12,24 , and $48 \mathrm{~h}$ compared to the control treated with distilled water. Under greenhouse conditions, all treatments in inoculated soils cultivated with tomato plants had reduced numbers of galls, egg-masses/plant, and the number of $\mathrm{J}_{2} / 250 \mathrm{~g}$ than the non-inoculated soil. The algal extract and the Oxamyl 24\% SL (5 m//l) increased the length and fresh weight of plant shoots and roots than the untreated. However, there were no differences in shoots and roots fresh weights and their lengths in the plant treated with Oxamyl 24\% SL (5 m//) or the extracts of U. fasciata and Corallina officinalis. These results were closely similar to control. Both of peroxidase and polyphenol enzymes activity for the control plants remained relatively stable, while the activity of the two enzymes in the plant inoculated with the nematode decreased during 2 to 18 day post inoculation (dpi). These activities increased in inoculated plants treated with C. officinalis, C. mediterranea, and U. fasciata extracts and the other plants treated with Oxamyl 24\% SL (5 ml/l). The maximum activity of the three enzymes was recorded at 5 dpi after treatment with U. fasciata.
\end{abstract}

Keywords: Meloidogyne incognita, Marine algae, Nematicide, Gene expression, Biocontrol

\section{Background}

Management of soil-borne plant pathogens, including parasitic nematodes, is one of the single greatest challenges facing modern agriculture worldwide. The importance of soil-borne pathogens in modern agriculture systems is the current rush worldwide.

The root-knot nematodes, Meloidogyne Göldi, 1892 (Rhabditida: Meloidogynidae) belongs to the most economically important plant that causes serious damage to most agricultural crops worldwide (Archidona-Yuste et al. 2018

\footnotetext{
* Correspondence: reyassin_ghareeb@yahoo.com

${ }^{1}$ Plant Protection and Biomolecular Diagnosis Department, Arid Lands Cultivation Research Institute (ALCRI), City of Scientific Research and Technological Applications, New Borg El Arab, 21934 Aexandria, Egypt Full list of author information is available at the end of the article
}

and Gareeb et al. 2019). Meloidogyne incognita is the most common species of root-knot nematodes that infects almost all cultivated plants, which makes it perhaps the most damaging of pathogens (Khalil and Darwesh 2018). Globally, it was estimated that the root-knot nematodes caused tomato yield losses by 27\% (Sharma and Sharma 2015).

For several decades, the use of chemical nematicide is one of the primary means of control for root-knot nematodes (Baidoo et al. 2017). Nowadays, chemical nematicide are losing their popularity among farmers for protecting their crops from nematode infestations because of their harmful effects and environmental pollution that led to an urgent need for safe and more effective options. Biological control promises to be such an option (Radwan and Farrag 2012; Saad et al. 2019). Recently, one of the 
biological control practices attempted is the study of suppression effects of cyanobacteria (blue-green algae) on the plant-parasitic nematodes. Cyanobacteria are little explored even today, so it may possess the novel metabolites which may not screen yet (Radwan and Farrag 2012). Microalgae metabolites have attracted attention, because they are a resource of active compounds, and potential new drugs (Shimizu 2003). The use of marine algae as control agent against plant-parasitic nematodes has been studied by many researchers (Youssef and Ali 1998). Different seaweeds exhibited very significant nematicidal activities (Zaki et al. 2005). Wu et al. (1997) reported the role of betaines in alkaline extracts of the marine brown algae Ascophyllum nodosum (Linnaeus) Le Jolis in suppression of the fecundity of tomato-knot nematodes Meloidogyne javanica and Meloidogyne incognita. Ibrahim et al. (2007) stated that treating sunflower plants with marine algae, Botryocladia cabillaceae caused reduction in root galls and egg masses of $M$. incognita as well as increased growth parameters. Khan et al. (2015) evaluated in vitro the nematicidal activity of 32 seaweeds on $M$. javanica egg hatching and larval mortality and recorded that Sargasssum tenerrimum, Padina tetrastromatica, and Melano thamnusafa qhusainii gave maximum egg hatching (96\%) and larval mortality (99\%) and (100\%), in water and methanol extract at $10 \%$ concentration after 72-h exposure time respectively.

Ulva fasciata Delile (UF) is a marine microalgae. It is a source of polyphenolic and diterpenoids compounds which have antibacterial properties and potential applications (Silva et al. 2013). Spirulina platensis is a micro alga belonging to Cyanophyceae class and comprise proteins, carbohydrates, essential fatty acids, vitamins, minerals especially (calcium and potassium), and pigments (Rosario and Josephine 2015).

The aim of this research was to evaluate the nematicidal potentiality of two red algae, Corallina mediterra$n e a$ and Corallina officinalis and other green algae, $U$. fasciata Delile on the root-knot nematode $M$. incognita infecting tomato plant under the laboratory and greenhouse conditions.

\section{Materials and methods}

\section{Algae material and preparation of ethanolic extracts}

Samples of the red algae, Corallina mediterranea, C. officinalis and the green alga, Ulva fasciata Delile were provided by the National Institute of Oceanography and Fisheries (NIOF), Alexandria, Egypt.

The dried algae were powdered, using an electrical grinder, and $50 \mathrm{~g}$ of each algal powder were extracted in $500 \mathrm{ml}$ of ethanol at $35^{\circ} \mathrm{C}$ under regular stirring for 5 days. The extract was filtered through a Whatman No. 1 filter and evaporated to dryness in rotary vacuum evaporator (Unipan type $350 \mathrm{p}$, Poland) at $35{ }^{\circ} \mathrm{C}$. The dried extracts were dissolved in ethanol to give $20 \mathrm{mg} / \mathrm{ml}$ stock solution, which was stored in airtight bottles at $4{ }^{\circ} \mathrm{C}$ and further diluted as per dose requirement.

\section{Root-knot nematode culture and inoculum preparation}

Root-knot nematode, Meloidogyne incognita (Kofoid and White) Chitwood, inocula was prepared from a pure culture established from single egg mass and reared in eggplant (Solanum melongena L. cv. Black Beauty) which was grown in the greenhouse of the Faculty of Agriculture, Damanhur University, Egypt. Morphological characteristics of the female perineal patterns were used to identify M. incognita (Taylor and Sasser 1978). Eggs were extracted from the egg masses of the infected eggplant roots by sodium hypochlorite $(\mathrm{NaOCl})$ solution (Hussey and Barker 1973), allowed to hatch in sterile distilled water at $25 \pm 2{ }^{\circ} \mathrm{C}$ and newly hatched secondstage juveniles $\left(\mathrm{J}_{2}\right)$ were collected for in vitro and pot experiments.

\section{In vitro experiments}

In vitro nematicidal activity of the three marine algal extracts, $C$. mediterranea, $C$. officinalis, and $U$. fasciata, at the concentrations of $0.125,0.25,0.5$, and $1 \mathrm{mg} / \mathrm{ml}$ in a sterile distilled water were tested against $M$. incognita. For egg hatching test, $0.1 \mathrm{ml}$ of water suspension containing 100 nematode eggs were transferred to glass vial containing $1 \mathrm{ml}$ of double concentrations of tested extracts solutions and incubated at $25 \pm 2{ }^{\circ} \mathrm{C}$ for 3,5 , and 7 days. After incubation, hatched juveniles were counted under light microscope (Olympus CX41RF, Olympus Optical Co., LTD) and egg hatching percentage was estimated.

The mortality of $\mathrm{J}_{2}$ was estimated by mixing $1 \mathrm{ml}$ of water suspension containing 50 new-hatched $\mathrm{J}_{2}$ with $1 \mathrm{ml}$ of double concentrations of tested extracts on glass vial and incubated at $25 \pm 2{ }^{\circ} \mathrm{C}$ for 12,24 , and $48 \mathrm{~h}$ (Khan et al. 2016). After incubation, $J_{2}$ were transferred in distilled water for $24 \mathrm{~h}$, active and dead nematodes were counted by the microscope (Olympus CX41RF, Olympus Optical Co., LTD). The \% mortality was calculated using Abbott's Formula (Abbott, 1925) as follows:

$$
\text { Juvenile mortality }(\%)=(m-\mathrm{n}) /(100-n) \times 100
$$

Where $m$ and $n$ are percentages of dead juveniles in the treatment and control, respectively.

Glass vials containing $1 \mathrm{ml}$ of a sterile distilled water contained either eggs or $\mathrm{J}_{2}$ suspension were served as control. The chemically synthesized nematicide, Oxamyl 24\% SL (5 ml/l, DuPont Company, USA), was used for comparison. Five replicates with four vials per replicate were used for each concentration and the experiment was repeated three times. 


\section{Pot experiment}

Surface-sterilized seeds of tomato (Lycopersicon esculentum Mill cv. Alisa) were germinated in seedling trays filled with a sterilized peat moss and allowed to grow up in the greenhouse for 4 weeks. Healthy and uniform 4-week-old seedlings were transplanted on plastic pots (one seedling per pot) of $20 \mathrm{~cm}$ diameter filled with $2.5 \mathrm{~kg}$ mixture of autoclaved sand and clay (3:1, v:v). Plants were kept on the greenhouse at $27-32{ }^{\circ} \mathrm{C}$ under natural daylight length conditions, watered once every 2 days, and fertilized once a week with commercial fertilizer with N (20\%), P (20\%), $\mathrm{K}(20 \%)$, and S (1.26\%) (Vascon 20-20-20, Farmers for Agriculture Development, Egypt) at the rate of $2 \mathrm{~g} / \mathrm{l}$ of water until the end of the experiment.

Ten days after transplanting, each pot was inoculated with 5000 eggs and freshly hatched $J_{2}$. Ten milliliters of water suspension of eggs and $J_{2}$ were pipetted into four holes of $5 \mathrm{~cm}$ depth around the plant roots zone and the holes were covered immediately with soil. Treatments included $C$. mediterranea, $C$. officinalis, and $U$. fasciata extracts at $1 \mathrm{mg} / \mathrm{ml}$ and Oxamyl 24\% SL (5 ml/l) at recommended rate $(5 \mathrm{ml} / \mathrm{l})$ were applied as soil drench in $150 \mathrm{ml}$ water per pot. All treatments were applied twice, after 2 days of transplanting and directly after inoculation. Untreated un-inoculated and untreated inoculated (nematode alone) pots served as controls. The experiment was arranged in a randomized block design with 20 replicates (pots) per treatment. Five replicates were used for nematode assay and the remaining replicates were used for enzymes and genes expression analysis. The experiment was repeated twice.

Plants were uprooted after 60 days of inoculation and gently washed with a running tap water, then shoot and root lengths $(\mathrm{cm})$ and fresh weights $(\mathrm{g})$ were recorded and the increase percentage over untreated inoculated control were estimated. Roots were stained in $0.015 \%$ Phloxine B solution for 15-20 min (Holbrook et al. 1983) and numbers of nematode galls, egg-masses, and eggs/plant root were counted and recorded (Taylor and Sasser 1978). Second stage juveniles $\left(\mathrm{J}_{2}\right)$ were extracted and counted from $250 \mathrm{~cm}^{3}$ soil per pot using the bucket sieving technique (Cobb 1918). Reduction percentage in nematode parameters over untreated inoculated control was calculated as following: Reduction $\%=[($ numbers in the control treatment - numbers in the treated plants) / number in control treatment $\times 100$. Reproduction factor $(\mathrm{RF})$ was also calculated as following: $(\mathrm{RF})=\mathrm{Pf} / \mathrm{Pi}$, where $\mathrm{Pf}=$ Final nematode population $=$ number of eggs $/$ plant + number of $\mathrm{J}_{2} /$ pot at the harvest time and $\mathrm{Pi}=$ initial nematode population $=$ 5000 eggs and $\mathrm{J}_{2}$.

\section{Activity of the antioxidant enzymes}

Peroxidase (POD) and polyphenol oxidase (PPO) were determined in tomato roots after $0,2,5,10$, and 18 days post inoculation (dpi). Three plants (replicates) per treatment were randomly collected at each specific sampling time, rinsed with demineralized water and stored at $-80{ }^{\circ} \mathrm{C}$ for further analysis. The same root samples were used for the quantification of gene expression at the same time points.

One gram of root was homogenized in $5 \mathrm{ml}$ extraction buffer (50 mM phosphate buffer, $\mathrm{pH}$ 7.0, $1 \mathrm{mM}$ EDTA, and $2 \%$ poly vinyl pyrrolidone, PVPP) in an ice-cold mortar. The homogenate was centrifuged at $12,000 \times g$ for $20 \mathrm{~min}$ at $4{ }^{\circ} \mathrm{C}$ (Universal 32R, Hettich Zentrifugen, Germany) and the supernatant was used for enzyme activity assays (Jakovljevicet et al. 2017).

POD and PPO activity assays were performed as described by Hussey et al. (1972). For POD activity assay, $0.1 \mathrm{ml}$ of enzyme extract was incubated with $1.5 \mathrm{ml}$ of 0.05 pyrogallol and $0.5 \mathrm{ml}$ of $1 \% \mathrm{H}_{2} \mathrm{O}_{2}$. The change in the absorbance was recorded at $20 \mathrm{~s}$ interval for $3 \mathrm{~min}$ at $420 \mathrm{~nm}$ (Jenway, Model 6305, Bibby Scientific Limited, UK). Enzyme activity was expressed as increase in the absorbance ( $\triangle$ OD420) $\mathrm{min}^{-1} \mathrm{~g}^{-1}$ of fresh weight (FW) (Hammerschmidt and Kuae 1982). PPO activity was determined by adding $200 \mu \mathrm{l}$ of enzyme extract to $1.5 \mathrm{ml}$ of $0.1 \mathrm{M}$ phosphate buffer (pH 6.5) and $200 \mu \mathrm{l}$ of $10 \mathrm{mM}$ catechol. The changes in absorbance were recorded for $1 \mathrm{~min}$ at $495 \mathrm{~nm}$. Enzyme activity was presented as $\triangle \mathrm{OD} 495 \mathrm{~min}^{-1} \mathrm{~g}^{-1} \mathrm{FW}$ (Mayer et al. 1965).

\section{Expression analysis of the peroxidase and polyphenol oxidase and chitinase genes using real-time qPCR}

Total RNA was isolated from root tissues sampled after 0 , 2, 5, 10, and 18 dpi using GStract ${ }^{\mathrm{TM}}$ RNA isolation kit II (Maxim Biotech INC, USA) according to the manufacturer's protocol. First-strand cDNA was synthesized from total RNA with oligo (dT) primer, dNTPS and M-MLV Reverse Transcriptase enzyme (Fermentas, USA) according to the standard protocol. QRT-PCR were performed for POD, PPO, and chitinase (Chit) genes. The tomato $18 \mathrm{~S}$ rRNA gene was used as internal reference (housekeeping) gene (Nassar and Adss 2016; Jayanna and Umesha 2017).

The following primers were used in the RT-PCR reaction: POD (Jogaiah et al. 2013), F-5'-GCTTTGTCAGGGGTTG TGAT-3', R-5'-TGCATCTCTAGCAACCAAC-3', PPO (Goel et al. 2017), F-5'-CATGCTCTTGATGAGGCGTA3', R-5'-CCATCTATGGAACGGGAAGA-3', Chit (Amar al et al. 2012), F-5'-AGTGCAGGAACATTCACTGGAGG A-3', R-5' -ACACCAATACCTTGTCCAGCTCGT-3', $18 \mathrm{~S}$ rRNA (Jayanna and Umesha 2017), F-5'-GTGCATGGC CGTTCTTAGTTG-3', R 5'-CAGGCTGAGGTCTCGTT CGT-3'. The RT-PCR Reaction (25 $\mu$ l) contained $12.5 \mu$ of $2 \times$ Quantitech SYBR ${ }^{\circ}$ Green RT Mix (Fermentas, USA), $1 \mu \mathrm{l}$ of $10 \mathrm{pmol} / \mu \mathrm{l}$ of each primer, $1 \mu \mathrm{l}$ of template cDNA (50 ng), and $9.5 \mu \mathrm{l}$ of RNase free water. The PCR reaction included an initial denaturation at $95{ }^{\circ} \mathrm{C}$ for $10 \mathrm{~min}$ 
followed by 40 cycles of denaturation at $95{ }^{\circ} \mathrm{C}$ for $15 \mathrm{~s}$, annealing at $60{ }^{\circ} \mathrm{C}$ for $30 \mathrm{~s}$ and extension at $72{ }^{\circ} \mathrm{C}$ for $30 \mathrm{~s}$, and a final extension of $72{ }^{\circ} \mathrm{C}$ for $10 \mathrm{~min}$ (Chin et al. 2000). The reaction was performed using a Rotor-Gene 6000 (Qiagen, ABI System, USA). Relative quantification of gene expression was performed by ( $\Delta \mathrm{C} q=\mathrm{C} q$ - reference gene, $\Delta \Delta \mathrm{C} q=\mathrm{C} q-$ control, and $\Delta \Delta \mathrm{C} q$ expression $=2$ $(-\Delta \Delta \mathrm{Cq})$ (Livak and Schmittgen 2001). The expression levels of the target genes were normalized relative to $18 \mathrm{~S}$ rRNA gene and relative expression of untreated control plants at each time were set as 1.

\section{Statistical analysis}

Data collected from in vitro and pot experiments were analyzed by two-way analysis of variance (treatments and times) using SAS version 9.4 (SAS Institute Inc., Cary, NC, USA). Treatment means were separated by Duncan's multiple range test at 5\% probability. Data of enzymes activity and gene expression were analyzed with GraphPad PRISM version 7 (GraphPad Software Inc., California, USA). Tukey's HSD test was used to determine the significant differences between means at a probability level of $\leq 0.05$.

\section{Results and discussion}

The nematicidal effect of the used concentrations of $C$. mediterranea, $C$. officinalis, and $U$. fasciata extracts in addition to the nematicide, Oxamyl $24 \% \mathrm{SL}(5 \mathrm{ml} / \mathrm{l})$, on the egg hatching and $J_{2}$ mortality of $M$. incognita was investigated and the results revealed that, on the third day of treatment, $21.6 \%$ of eggs hatched and increased to $52.6 \%$ on the seventh day in the control group. All treatments at the applied concentrations suppressed $(P \leq 0.05)$ the egg hatching at 3, 5, and 7 days than the untreated control (Table 1). Moreover, the extract of $U$. fasciata was the highly active in decreasing eggs hatchability, as it caused (2-4\%) egg hatching with (81.4-87\%) inhibition of hatchability after the exposure for 3 days. Slight decrease in egg hatching and inhibition of egg hatchability was observed with the increase in algal extract concentrations. On the other hand, Oxamyl 24\% SL (5 ml/l) showed severe suppression of nematode the hatchability of egg $(0.2-1.4 \%)$ with 97\% inhibition after the exposure of 3 days of treatment (Table 1). $U$. fasciata was the most active extract in decreasing the hatchability of eggs. Moreover, Oxamyl 24\% SL $(5 \mathrm{ml} / \mathrm{l})$ caused severe suppression of the hatchability of nematode eggs. These findings agreed with the results obtained by Khan et al. (2009), who reported that the marine algae seaweed species not only control the nematode in soil but also it increased the health of both the soil and the plant. The same observation was reported by Khan et al. (2017), who reported that ethanol extract of $U$. fasciata possesses the highest nematicidal activity than water extract.
Table 1 Effect of three marine algal extracts on egg hatchability and inhibition percentages (1\%) of the root-knot nematode, Meloidogyne incognita under laboratory conditions

\begin{tabular}{|c|c|c|c|c|c|c|}
\hline \multirow[t]{2}{*}{ Treatments } & \multicolumn{6}{|c|}{ Eggs hatching (\%) Exposure time (days) } \\
\hline & 3 days & $1 \%$ & 5 days & $1 \%$ & 7 days & $1 \%$ \\
\hline Control & $21.60^{a}$ & 0.0 & $36.20^{a}$ & 0.0 & $52.60^{a}$ & 0.0 \\
\hline \multicolumn{7}{|c|}{ Corallina mediterranea mg/ml } \\
\hline 0.125 & $7.80^{\mathrm{b}}$ & 64 & $16.20^{\mathrm{b}}$ & 55.2 & $21.75^{\mathrm{b}}$ & 40.60 \\
\hline 0.25 & $5.80^{\mathrm{cd}}$ & 73.1 & $13.00^{\mathrm{cd}}$ & 64 & $17.25^{\mathrm{cd}}$ & 34.60 \\
\hline 0.5 & $5.20^{\mathrm{de}}$ & 76 & $12.20^{\text {de }}$ & 66.2 & $15.75^{\text {de }}$ & 48.40 \\
\hline 1 & $5.00^{\mathrm{de}}$ & 76.8 & $12.00^{\text {de }}$ & 66.8 & $15.25^{\text {de }}$ & 70.20 \\
\hline \multicolumn{7}{|c|}{ Corallina officinalis mg/ml } \\
\hline 0.125 & $6.80^{\mathrm{bc}}$ & 68.5 & $14.80^{\mathrm{bc}}$ & 59 & $19.50^{\mathrm{bc}}$ & 36.40 \\
\hline 0.25 & $6.40^{\mathrm{bcd}}$ & 70.3 & $13.80^{c d}$ & 61.8 & $18.25^{\mathrm{cd}}$ & 51.00 \\
\hline 0.5 & $6.00^{c d}$ & 72.2 & $13.60^{\mathrm{cd}}$ & 62.4 & $17.75^{\mathrm{cd}}$ & 55.60 \\
\hline 1 & $5.60^{c d}$ & 74 & $13.00^{c d}$ & 64 & $16.75^{\mathrm{cd}}$ & 57.20 \\
\hline \multicolumn{7}{|c|}{ Ulva fasciata $\mathrm{mg} / \mathrm{ml}$} \\
\hline 0.125 & $4.00^{\mathrm{ef}}$ & 81.4 & $10.40^{\mathrm{ef}}$ & 71.2 & $13.00^{\mathrm{e}}$ & 34.60 \\
\hline 0.25 & $3.00^{f}$ & 86 & $9.00^{f}$ & 75 & $10.75^{f}$ & 54.00 \\
\hline 0.5 & $3.00^{f}$ & 86 & $9.20^{f}$ & 74.5 & $10.75^{f}$ & 66.80 \\
\hline 1 & $2.80^{f}$ & 87 & $8.80^{f}$ & 75.6 & $10.00^{f}$ & 70.20 \\
\hline Oxamyl $5 \mu \mathrm{l} / \mathrm{ml}$ & $0.20^{9}$ & 99 & $0.80^{9}$ & 97.7 & $1.40^{9}$ & 97.3 \\
\hline
\end{tabular}

Means followed by the same letter (s) are not significantly different by Duncan's multiple range test $(P \leq 0.05)$

Data in Table 2 showed that all treatments were significantly $(P \leq 0.05)$ increased $\mathrm{J}_{2}$ mortality percentage after 12,24 , and $48 \mathrm{~h}$ than the untreated inoculated control. Moreover, there was stepwise increase in $\mathrm{J}_{2}$ mortality percentages with increasing the concentrations and exposure time. Both of $C$. officinalis and $U$. fasciata extracts appeared to be the most active algae as they caused 80.40 and $85 \%$ mortality of $\mathrm{J}_{2}$ larvae in vitro after $12 \mathrm{~h}$ of exposure to the concentration of 0.5 or $1 \mathrm{mg} / \mathrm{ml}$ respectively, Their nematicidal activity were significantly equal with Oxamyl 24\% SL (5 ml/l) (95.6\%). The same observation was recorded by Paracer et al. (1987), who found that using of the marine algal extracts of Botryocladia occidentalis and Bryothamnion triquestrum (in concentrations $0.5-1 \%$ ) in soil application showed a high reduction of root gall in the infected plants with $M$. incognita. Also, these results agreed with what Jacobs et al. 2003 and Jiménez et al. (2011) postulated, that the algae contain chemical compounds that are able to control a wide range of plant pathogens. Under greenhouse conditions, the three tested marine algae (C. mediterranea, $C$. officinalis, and $U$. fasciata) extracts at conc. $1 \mathrm{mg} / \mathrm{ml}$, and the comparable nematicide Oxamyl 24\% SL (5 ml/l) at $5 \mu \mathrm{l} / \mathrm{ml}$, significantly suppressed the development and the reproduction of nematode with no toxic effects the tomato plants. All treatments significantly $(P \leq 0.05)$ 
Table 2 Effect of three marine algal extracts on $J_{2}$ mortality of Meloidogyne incognita under laboratory conditions

\begin{tabular}{|c|c|c|c|}
\hline \multirow[t]{2}{*}{ Treatments } & \multicolumn{3}{|c|}{$\mathrm{J} 2$ mortality (\%) Exposure time (h) } \\
\hline & $12 \mathrm{~h}$ & $24 h$ & $48 \mathrm{~h}$ \\
\hline Control & $8.40^{f}$ & $13.40^{f}$ & $14.60^{f}$ \\
\hline \multicolumn{4}{|c|}{ Corallina mediteranea mg/ml } \\
\hline 0.125 & $46.75^{\text {de }}$ & $18.40^{\text {de }}$ & $18.40^{\text {de }}$ \\
\hline 0.25 & $39.00^{\mathrm{e}}$ & $14.80^{e}$ & $14.80^{e}$ \\
\hline 0.5 & $57.00^{c d}$ & $23.20^{\mathrm{cd}}$ & $23.20^{\mathrm{cd}}$ \\
\hline 1 & $85.00^{\mathrm{a}}$ & $35.60^{a}$ & $35.60^{\mathrm{a}}$ \\
\hline \multicolumn{4}{|c|}{ Corallina officinalis mg/ml } \\
\hline 0.125 & $41.50^{\mathrm{e}}$ & $16.20^{\mathrm{e}}$ & $16.20^{e}$ \\
\hline 0.25 & $60.25^{\text {cd }}$ & $24.60^{c d}$ & $24.60^{c d}$ \\
\hline 0.5 & $66.00^{\mathrm{bc}}$ & $26.80^{\mathrm{bc}}$ & $26.80^{b c}$ \\
\hline 1 & $68.00^{b c}$ & $27.60^{\mathrm{bc}}$ & $27.60^{b c}$ \\
\hline \multicolumn{4}{|c|}{ Ulva fasciata mg/ml } \\
\hline 0.125 & $39.25^{\mathrm{e}}$ & $15.40^{\mathrm{e}}$ & $15.40^{\mathrm{e}}$ \\
\hline 0.25 & $63.75^{c}$ & $25.60^{c}$ & $25.60^{c}$ \\
\hline 0.5 & $80.40^{\mathrm{ab}}$ & $33.20^{\mathrm{ab}}$ & $33.20^{a b}$ \\
\hline 1 & $85.00^{\mathrm{a}}$ & $35.60^{\mathrm{a}}$ & $35.60^{\mathrm{a}}$ \\
\hline Oxamyl5 $1 / / \mathrm{ml}$ & $40.00^{\mathrm{a}}$ & $78.60^{a}$ & $95.60^{a}$ \\
\hline
\end{tabular}

Mortality $=$ [number of dead juveniles $J_{2} /$ total number of juveniles $\left.J_{2}\right] \times 100$ Means followed by the same letter (s) are not significantly different by Duncan's multiple range test $(P \leq 0.05)$

reduced the numbers of galls, egg-masses, number of eggs/plant root, number of $J_{2} / 250 \mathrm{~cm}^{3}$ of soil, and reproduction factor (RF) than the untreated inoculated plants (Table 3). Generally, the nematicide Oxamyl $24 \%$ SL $(5 \mathrm{ml} / \mathrm{l})$ was the best treatment in reducing gall number per root by $99.3 \%$; while, $U$. fasciata was the most effective algae extract, resulted in $77.5 \%$ reduction, followed by C. officinalis and C. mediterranea, with 50.3 and $34.7 \%$ reduction, respectively (Table 3 and Fig. 1). Same trend was observed in number of egg masses/plant root, number of eggs/plant root, and number of $\mathrm{J}_{2} /$ $250 \mathrm{~cm}^{3}$ of soil. The reduction percentages recorded in egg masses per plant root due to the same aforementioned treatments were 99.6, 74, 58.5, and 39\%. These treatments reduced number of eggs/plant root by 99.6 , 75.6, 62.4, and $40.3 \%$. Treatments also suppressed $M$. incognita $\mathrm{J}_{2}$ in the soil by $100,73.2,68.6$, and $36.4 \%$, respectively, with insignificant difference between $U$. fasciata and C. officinalis. The highest reduction percentages in RF were recorded by Oxamyl 24\% SL ( $5 \mathrm{ml} / \mathrm{l}$.) (99.6\%) followed by $U$. fasciata (75.7\%), C. officinalis (62.4\%), and C. mediterranea (40.3\%) (Fig. 1). The impact of marine algal extracts and the nematicide, Oxamyl $24 \% \mathrm{SL}(5 \mathrm{ml} / \mathrm{l})$, on growth parameters of nematode infected tomato plants under greenhouse conditions were recorded in Table 4. Data showed that the tested marine algal extracts and Oxamyl 24\% SL (5 ml/l) significantly $(P \leq 0.05)$ increased the length and fresh weight of plant shoots and roots compared to infected control. However, shoots and roots fresh weights and lengths were similar between the nematicide, Oxamyl 24\% SL (5 ml/l), $U$. fasciata and C. officinalis and they do not differ significantly from the uninfected control (healthy). Nour ElDeen and Issa (2016) reported that the use of the algal extracts for seven marine algae in concentration $60-80 \%$ made reduction in egg hatching with percentage ranged from 2 to $4 \%$. But for the larval stage, the toxicity of some of these extracts reached up to $90 \%$ after 4 days of treatment. Several studies postulated the nematicidal activity of the algal extract because it contains various compounds which have synergistic activity against the phytopathogenic nematodes (Fornes et al. 2002; Vernieri et al. 2005; Gil-Chávez et al. 2013). Subsequently, the treated plants with algal extracts may increase the crops growth parameters; this normally happened may be due to the presence of some growth-promoting substances in the marine algal extract (Blunden 1991).

\section{Peroxidase and polyphenol oxidase enzyme activities}

The results illustrated in Fig. 2 showed that peroxidase (POD) and polyphenol oxidase (PPO) enzyme activities of the control plants remained relatively stable, while the inoculation with nematode ( $M$. incognita) significantly increased the activities during 2 to $18 \mathrm{dpi}$. These activities were remarkably increased in inoculated plants treated with C. officinalis $(\mathrm{Co}+\mathrm{N})$, C. mediterranea $(\mathrm{Cm}+\mathrm{N}), U$. fasciata $(\mathrm{Uf}+\mathrm{N})$ extracts, and the nematicide Oxamyl $24 \%$

Table 3 Effect of three marine algal extracts against the root-knot nematode, Meloidogyne incognita galls, egg masses, eggs on roots, and second stage $J_{2}$ population in soil of tomato plants under greenhouse conditions

\begin{tabular}{llllll}
\hline Treatment & Number of galls/plant & Number of egg masses/plant & Number of eggs/plant & Number of $\mathrm{J}_{2} / 250 \mathrm{~cm}^{3}$ of soil & $R F$ \\
\hline Inf. Control & $353^{\mathrm{a}}$ & $367^{\mathrm{a}}$ & $152402^{\mathrm{a}}$ & $382^{\mathrm{a}}$ & $30.78^{\mathrm{a}}$ \\
Corallina mediteranea & $230^{\mathrm{b}}$ & $224^{\mathrm{b}}$ & $90990^{\mathrm{b}}$ & $243^{\mathrm{b}}$ & $18.39^{\mathrm{b}}$ \\
Corallina officinalis & $175^{\mathrm{c}}$ & $152^{\mathrm{c}}$ & $57265^{\mathrm{c}}$ & $120^{\mathrm{c}}$ & $11.55^{\mathrm{c}}$ \\
Ulva fasciata & $79.3^{\mathrm{d}}$ & $95.5^{\mathrm{d}}$ & $37120^{\mathrm{d}}$ & $103^{\mathrm{c}}$ & $7.51^{\mathrm{d}}$ \\
Oxamyl $15 \mu / \mathrm{ml}$ & $2.60^{\mathrm{e}}$ & $1.60^{\mathrm{e}}$ & $564^{\mathrm{e}}$ & $0.00^{\mathrm{d}}$ & $0.11^{\mathrm{e}}$ \\
\hline
\end{tabular}

Inf. control infected control, means followed by the same letter are not significantly different by Duncan's multiple range test $(P \leq 0.05)$ 


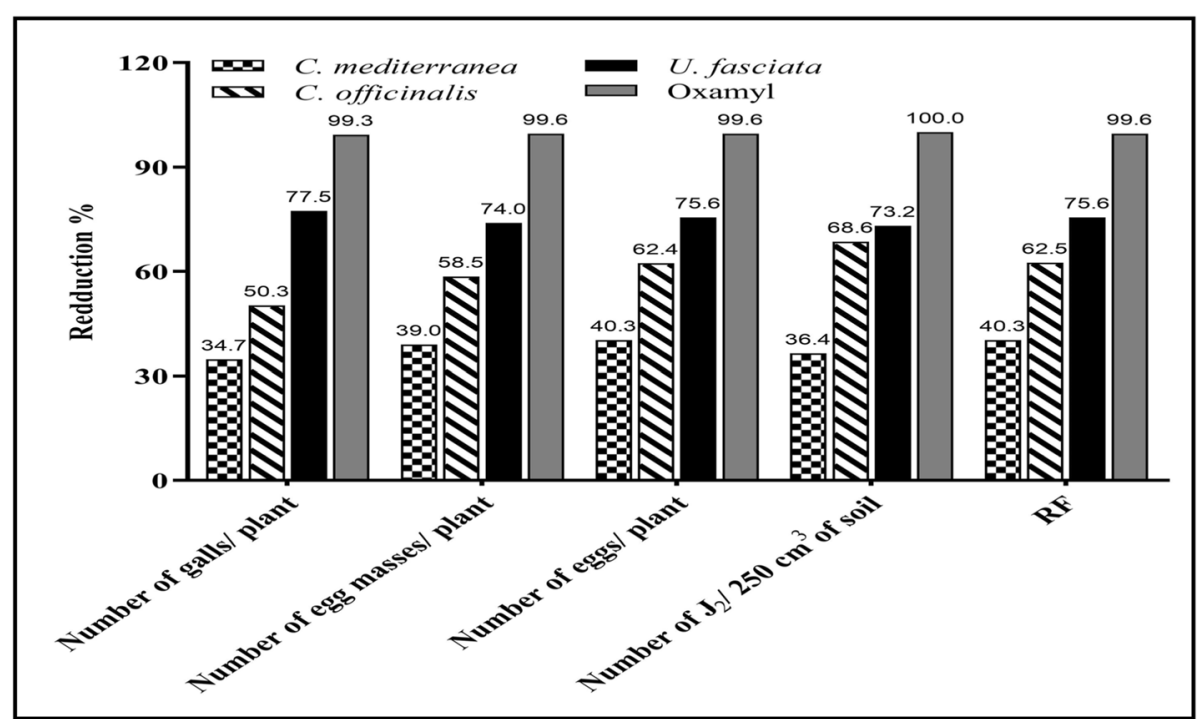

Fig. 1 Reduction percentage of nematode galls, egg masses, eggs/plant root, second stage $J_{2}$ population in soil and reproduction factor (RF.) of tomato plants inoculated with M. incognita and treated with C. mediterranea, C. officinalis, U. fasciata extracts and the nematicide, oxamyl under greenhouse conditions

SL $(5 \mathrm{ml} / \mathrm{l})$. POD and PPO activities of all treatments began to increase significantly at $2 \mathrm{dpi}$, reached highest values at $5 \mathrm{dpi}$, then reduced gradually at 10 and $18 \mathrm{dpi}$ but still maintained a relatively higher level than 0 dpi. Infected plants treated with $U$. fasciata $(\mathrm{Uf}+\mathrm{N})$ resulted in the highest activity level of both enzymes and reached a maximal level at $5 \mathrm{dpi}$, which were approximately 1.81 - and 1.57 -fold higher than that in nematode-inoculated plants, and 2.29- and 2.22-fold that in un-inoculated control plants for POD and PPO, respectively (Fig. 2a, b). However, the activity of POD and PPO did not differ significantly between $U$. fasciata $(\mathrm{Uf}+\mathrm{N})$ and C. officinalis $(\mathrm{Co}+\mathrm{N})$ at 2 and $10 \mathrm{dpi}$ (Fig. 2a). Moreover, there is insignificant difference in PPO activity between $C$. officinalis $(\mathrm{Co}+\mathrm{N})$ and $C$. mediterranea $(\mathrm{Cm}+\mathrm{N})$ at all sampling times (Fig. 2b). Bhargava et al. (2007) has observed that increased phenolic concentration infected with $M$. incognita. The enzymes which are produced in defending the plant against the pathogen may be high because the treated plants are still under the stress of the nematode infection. This suggestion is supported by the results obtained in this study and the results of Thompson (2004). It was reported that the seaweed extract increase the plant immune system and increase its capability to resist the abiotic and biotic stresses (Santaniello et al. 2017). Moreover, algal extract could help in stimulating the plants' enzymatic and non-enzymatic antioxidative systems which play an important role in plant defense against the pathogens (Baxter et al. 2014; Das and Roychoudhury 2014). Also, the high production of the antioxidant compounds such as phenols, ascorbic acid, reduced glutathione, flavonoids, and carotenoids plays an important role in plant defense against the plant pathogens (Foyer and Noctor 2005; Gill and Tuteja 2010).

Table 4 Effect of three marine algal extracts against the root-knot nematode, Meloidogyne incognita on vegetative growth parameters of tomato plants grown in the greenhouse

\begin{tabular}{|c|c|c|c|c|c|c|c|c|}
\hline \multirow[t]{2}{*}{ Treatments } & \multicolumn{4}{|c|}{ Fresh weight (g) } & \multicolumn{4}{|c|}{ Length $(\mathrm{cm})$} \\
\hline & Shoot & $1 \%$ & Root & $1 \%$ & Shoot & $1 \%$ & Root & $1 \%$ \\
\hline Inf. control & $27.00^{c}$ & - & $12.60^{c}$ & - & $28.00^{c}$ & - & $24.40^{b}$ & - \\
\hline Ulnf. control & $42.60^{\mathrm{a}}$ & 57.78 & $21.80^{\mathrm{a}}$ & 73.02 & $42.20^{\mathrm{a}}$ & 50.71 & $31.60^{\mathrm{a}}$ & 29.51 \\
\hline Corallina mediteranea & $33.00^{\mathrm{b}}$ & 22.22 & $15.60^{b}$ & 23.81 & $33.20^{b}$ & 18.57 & $29.80^{a}$ & 22.13 \\
\hline Corallina officinalis & $39.50^{\mathrm{a}}$ & 46.30 & $19.15^{\mathrm{a}}$ & 51.98 & $41.71^{a}$ & 48.96 & $30.54^{a}$ & 25.16 \\
\hline Ulva fasciata & $40.50^{\mathrm{a}}$ & 50.00 & $20.75^{\mathrm{a}}$ & 64.68 & $41.50^{\mathrm{a}}$ & 48.21 & $31.00^{\mathrm{a}}$ & 27.05 \\
\hline 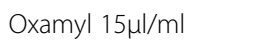 & $41.60^{\mathrm{a}}$ & 54.07 & $19.20^{\mathrm{a}}$ & 52.38 & $40.20^{a}$ & 43.57 & $30.80^{a}$ & 26.23 \\
\hline
\end{tabular}

Inf. control infected control, UI. nf. control uninfected control. Means followed by the same letter are not significantly different by Duncan's multiple range tests $(P \leq 0.05)$ 

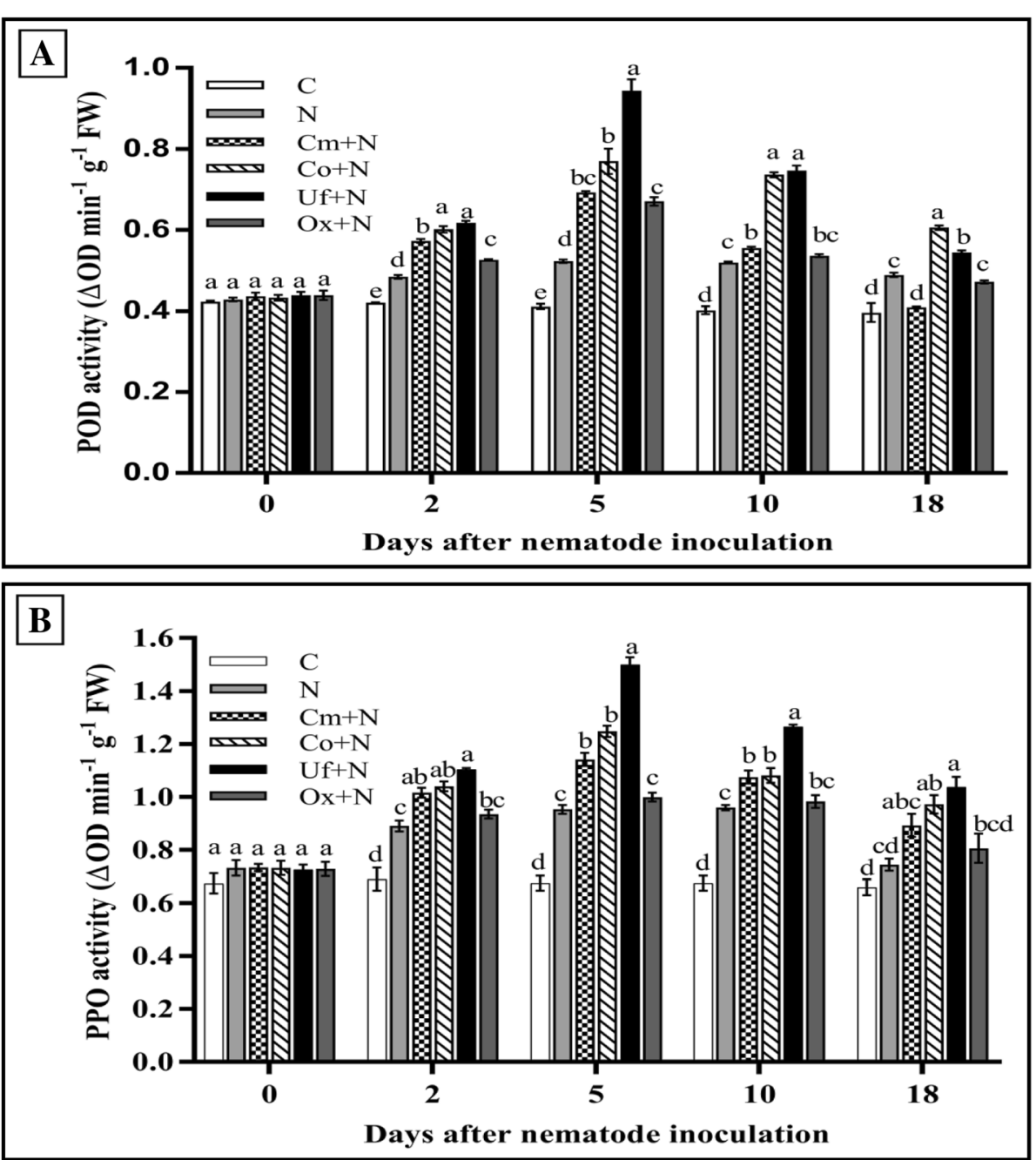

Fig. 2 Activities of POD (peroxidase) (a) and PPO (polyphenol oxidase) (b) enzymes in the roots of tomato plants inoculated with $M$. incognita ( $N$ ) and treated with $\mathrm{C}$. mediterranea $(\mathrm{Cm}+\mathrm{N})$, C. officinalis $(\mathrm{Co}+\mathrm{N})$, U. fasciata $(\mathrm{Uf}+\mathrm{N})$ extracts and the nematicide, oxamyl $(\mathrm{Ox}+\mathrm{N})$. Untreated uninoculated plants served as control (C). Values are the mean of three replicates \pm SE. Means followed by different letters within the same time considered different at $P \leq 0.05$ according to Tukey's HSD test

\section{Peroxidase, polyphenol oxidase, and chitinase gene expression}

The relative expression level of the three defense genes, POD, PPO, and chitinase, was quantified in roots of tomato plants inoculated with $M$. incognita and treated with different marine algal extracts, using quantitative real-time PCR. Expression profile of these genes was analyzed at $0,2,5,10$, and 18 dpi (Fig. 3b). Results show that expression of POD, PPO, and chitinase genes were induced by all applied treatments by different relative expression levels among treatments than the basal expression level of un-inoculated control (C). Induction of the three genes started early ( $2 \mathrm{dpi})$ in inoculated and treated plants and the greatest expression level was recorded on the fifth day than the relative expression levels of control (C) before decline at 10 and $18 \mathrm{dpi}$. The highest peak of POD, PPO, and chitinase accumulation (14.26-, 11.97-, and 18.56-folds) appeared at $5 \mathrm{dpi}$ in nematode-infected plants treated with $U$. fasciata (Uf + $\mathrm{N})$, respectively, higher than the control. Infection of the tomato roots by the nematodes alone caused significant induction of the three genes but was less compared to that in infected plant treated with algal extracts or Oxamyl 24\% SL (5 ml/l). Rani et al. (2008) found similar results that there was enhancement in the activities of PPO enzymes in the resistant cultivars of tomato. Feng and Shan (2014) reported that the ROS production was evolved in the early infection and it is considered one of the sudden response of the plant defense system against the pathogen. The general notice is that the algal extracts induced the plant defense genes which rustled in high rate production of the enzymes controlled by 

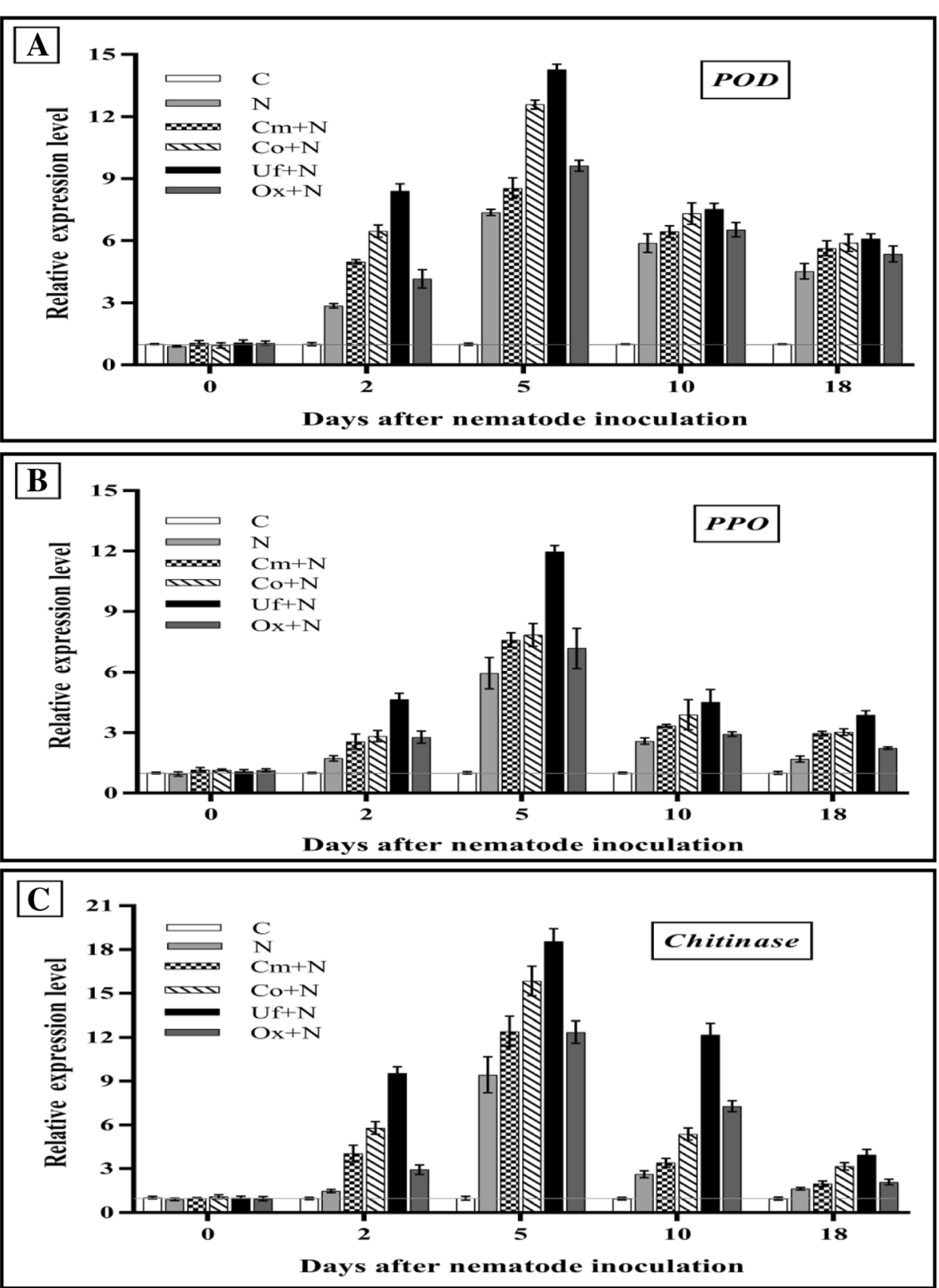

Fig. 3 POD (a), PPO (b), and chitinase (c) relative gene expression in roots of tomato plants inoculated with $M$. incognita $(\mathrm{N})$ and treated with $C$. officinalis $(\mathrm{Co}+\mathrm{N})$, C. mediterranea $(\mathrm{Cm}+\mathrm{N})$, U. fasciata $(\mathrm{Uf}+\mathrm{N})$ extracts and the nematicide, oxamyl $(\mathrm{Ox}+\mathrm{N})$. Untreated un-inoculated plants served as control (C). The expression level of the target genes were normalized relative to $18 \mathrm{~S}$ rRNA gene and relative expression of untreated control plants at each time were set as 1. Each value represents mean \pm S.E $(n=3)$

these genes (Torres et al. 2002). The high productions of these enzymes are considered as one of the acquired resistance for the plant against the plant pathogen and these results are in agreement with that of Arioli et al. (2015). On the other hand, it is well known that polyphenols are produced in high amount in the plant infected with nematode due to the high expression of their genes (Chin et al. 2018). Flavonoids can inhibit egg hatching and inhibited the larval motility (Wuyts et al.
2006), and rutin killed pre-parasitic stages of cyst nematodes (Faizi et al. 2011). Punja and Zhang (1993) reported that plant chitinases could affect the nematode development both in vitro and in vivo. It was reported that plant produces chitinase during the nematode infection because the chitin was discovered documented in the eggshells of various nematode species (Wan et al. 2008). Subsequently, the nematode infection cause high expression into some of the defence-related genes such 
as PR1 family; chitinase is one of this family (Bhattarai et al. 2008; (Kyndt et al. 2014).

\section{Conclusion}

U. fasciata extract exceeded the nematicidal activity. Thus, it can be used as safe and environmentally biological control agent against plant-parasitic nematodes. However, further studies on purification and isolation of the potent bioactive compounds are necessary to determine the most effective one.

\section{Abbreviations}

C. mediterranea: Corallina mediterranea; C. officinalis: Corallina officinalis; Chit: Chitinase; dpi: Day post inoculation; $J_{2}$ : Second-stage juveniles; Ml: Meloidogyne incognita; Pf: Final nematode population; Pi: Initial nematode population; POD: Peroxidase; PPO: Polyphenol oxidase; R: Reduction; RF: Reproduction factor; U. fasciata: Ulva fasciata

\section{Acknowledgements}

We are greatly indebted and thankful to Prof. Dr. Elsayed E. Hafez, Professor of Molecular Biology, City of Scientific Research and Technology Applications, Arid Lands Cultivation Research Institute (ALCRI), Plant Protection and Biomolecular diagnosis Department, Egypt for his help in the part of expression gene (Real Time PCR) part.

\section{Authors' contributions}

All authors contributed to the design of the experiment, acquisition of data, analysis and interpretation of data, and drafting and revision of the manuscript. All authors read and approved the final manuscript.

\section{Funding}

Self-funding.

\section{Availability of data and materials}

Not applicable in this section.

Ethics approval of human data or animal tissues

Not applicable in this section.

Ethics approval and consent to participate

Not applicable in this section.

\section{Consent for publication}

Not applicable in this section.

\section{Competing interests}

The authors declare that they have no competing interests.

\section{Author details}

${ }^{1}$ Plant Protection and Biomolecular Diagnosis Department, Arid Lands Cultivation Research Institute (ALCRI), City of Scientific Research and Technological Applications, New Borg El Arab, 21934 Aexandria, Egypt. ${ }^{2}$ Genatics Department, Faculty of Agriculture, Damanhour University, Damanhour, Egypt. ${ }^{3}$ Plant Pathology Department, Faculty of Agriculture, Damanhour University, Damanhour, Egypt.

Received: 2 May 2019 Accepted: 6 August 2019

Published online: 19 August 2019

\section{References}

Abbott WS (1925) A method of computing the effectiveness of an insecticide. J Econ Entomol 18:265-267

Amaral DOJ, de Almeida CMA, Correia MTS, Vera LM, Lima MV (2012) Isolation and characterization of chitinase from tomato infected by Fusarium oxysporum f. sp. Iycopersicum. J Phytopathol 160:741-744

Archidona-Yuste A, Cantalapiedra-Navarrete C, Lie'banas G, Rapoport HF, Castillo P, Palomares-Rius JE (2018) Diversity of root-knot nematodes of the genus Meloidogyne Goeldi, 1892 (Nematoda: Meloidogynidae) associated with olive plants and environmental cues regarding their distribution in southern Spain PLoS One 13(6):e0198236

Arioli T, Mattner SW, Winberg PC (2015) Applications of seaweed extracts in Australian agriculture: past, present and future. J Appl Phycol 27(5): 2007-2015

Baidoo R, Mengistu T, McSorley RR, Stamps H, Brito J, William TC (2017) Management of root-knot nematode (Meloidogyne incognita) on Pittosporum tobira under greenhouse, field, and on-farm conditions in Florida. J Nematol 49(2):133-139

Baxter A, Mittler R, Suzuki N (2014) ROS as key players in plant stress signalling. J Exp Bot 65(5):1229-40

Bhargava A, Shukla S, Ohri D (2007) Evaluation of foliage yield and leaf quality traits in Chenopodium spp. in multiyear trials. Euphytica 153:99-213

Bhattarai KK, Xie QG, Mantelin S, Bishnoi U, Girke T, Navarre DA, Kaloshian I (2008) Tomato susceptibility to root-knot nematodes requires an intact jasmonic acid signaling pathway. Mol Plant-Microbe Interact 21:1205-1121

Blunden G (1991) Agricultural uses of seaweeds and seaweed products. Wiley, Chichester, pp 65-81

Chin LS, Singh SK, Wang Q, Murray SF (2000) Identification of Okadaic-acid-induced genes by mRNA differential display in glioma cells. J Biomed Sci 7:152-159

Chin S, Behm CA, Mathesius U (2018) Functions of flavonoids in plant-nematode interactions. Plants (Basel) 7(4):85

Cobb NA (1918) Estimating the nema population of soil. USDA Technical Circular 1:48

Das K, Roychoudhury A (2014) Reactive oxygen species (ROS) and response of antioxidants as ROS-scavengers during environmental stress in plants. Front Environ Sci 2:5310

Faizi S, Fayyaz S, Bano S, Iqbal EY, Lubna, Siddiqi H, Naz A (2011) Isolation of nematicidal compounds from Tagetes patula L. yellow flowers: structureactivity relationship studies against cyst nematode Heterodera zeae infective stage larvae. J Agric Food Chem 59(17):9080-9093

Feng B, Shan L (2014) ROS open roads to roundworm infection. Sci Signal 7:pe10

Fornes F, Sa'nchez-Perales M, Guadiola JL (2002) Effect of a seaweed extract on the productivity of 'de Nules' clementine mandarin and navelina orange. Bot Mar 45:486-489

Foyer CH, Noctor G (2005) Redox homeostasis and antioxidant signaling: a metabolic interface between stress perception and physiological responses. Plant Cell 17:1866-1875

Gareeb RY, Elnouby MS, Hasan MA, Ticu S, Popa A, Bungau S, Hafez EE (2019) New trend for using the reduced graphene oxide as effective and ecofriendly Nematicide. Mater Plast 56:1

Gil-Chávez J, Fernando J, Basilio Heredia J, Sepulveda D, MYG E, González-Aguilar A (2013) Technologies for extraction and production of bioactive compounds to be used as nutraceuticals and food ingredients: an overview. Compr Rev Food Sci Food Saf 12(1):5-23

Gill SS, Tuteja N (2010) Reactive oxygen species and antioxidant machinery in abiotic stress tolerance in crop plants. Plant Physiol Biochem 48:909-930

Goel N, Anukrati K, Paul PK (2017) Biocontrol of bacterial speck of tomato by aqueous extract of Tagetes erecta. J Plant Protect Res 57(4):361-369.

Hammerschmidt RN, Kuae J (1982) Association of enhanced peroxidase activity with induced systemic resistance of cucumber to Colletotrichum lagenarium. Physiol Plant Pathol 20:73-82

Holbrook CC, Knauft DA, Dikson DW (1983) A technique for screening peanut for resistance to Meloidogyne arenaria. Plant Dis. 57:957-958.

Hussey RS, Barker KR (1973) Comparison of methods for collecting inocula of Meloidogyne spp., including a new technique. Plant Dis Rep 57:1025-1028

Hussey RS, Sasser JN, Huisingh D (1972) Disc-electrophoretic studies of soluble proteins and enzymes of $M$. incognita and M. arenaria. J Nematol 4:183-189

Ibrahim IKA, EL-Saedy MAM, Asmaa AA (2007) Control of the root-knot nematode Meloidogyne incognita on sunflower plants with certain organic plant materials and biocontrol agents. Egypt J Phytopathol 35(1):13-24

Jacobs H, Gray SN, Crump DH (2003) Interactions between nemato phagous fungi and consequences for their potential as biological agents for the control of potato cyst nematodes. Mycol Res 107:47-56

Jakovljević DZ, Topuzović MD, Stanković MS (2017) Changes in antioxidant enzyme activity in response to salinity-induced oxidative stress during early growth of sweet basil. Hortic Environ Biotechnol. 58:240.

Jayanna SK, Umesha S (2017) Enhancement of the expression of defense genes in tomato against Ralstonia solanacearum by N-octanoyl L-homoserine lactone. Afr J Microbiol Res 11(5):194-203 
Jiménez E, Dorta F, Medina C, Ramírez A, Ramírez I, Peña-Cortés H (2011) Antiphytopathogenic activities of macro-algae extracts. Mar Drugs. 9:739-756.

Jogaiah SM, Abdelrahman LP, Shin-ichi I (2013) Characterization of rhizosphere fungi that mediate resistance in tomato against bacterial wilt disease. J Exp Bot 64(12):3829-3842

Khalil MS, Darwesh DM (2018) Some integrated practices to manage root-knot nematodes on tomatoes: a mini review. Innov Tech Agric 3:2

Khan A, Mohd A, Moh T, Bushra R, Kavita P, Mansoor AS (2017) Phytochemical investigation, nematostatic and nematicidal potential of weeds extract against the root-knot nematode. Meloidogyne incognita in vitro. Asian J Biol Sci 10:38-46

Khan AM, Naz S, Abid M (2016) Evaluation of marine red alga Melanothamnus afaqhusainii against Meloidogyne incognita, fungus and as fertilizing potential on okra. Pak J Nematol 34(1):91-100 (Pakistan Society of Nematologists)

Khan S, Abid M, Hussain F (2015) Nematicidal activity of seaweeds against Meloidogyne javanica. Pak J Nematol 33(2):195-203 (Pakistan Society of Nematologists)

Khan W, Rayirath UP, Subramanian S, Jithesh MN, Rayorath R, Mark HD, Critchley AT, James SC, Norri J, Prithiviraj A (2009) Seaweed extracts as biostimulants of plant growth and development. J Plant Growth Regul 28(4):386-399

Kyndt T, Fernandez D, Gheysen G (2014) Plant-parasitic nematode infections in rice: molecular and cellular insights. Annu Rev Phytopathol 52:135-153

Livak KJ, Schmittgen TD (2001) Analysis of relative gene expression data using real-time quantitative PCR and the 2 (-Delta Delta C (T) method. Methods 25:402-408

Mayer AM, Harel E, Shaul RB (1965) Assay of catechol oxidase a critica1 comparison of methods. Phytochemisty 5:783-789

Nassar AMK, Adss IAA (2016) 2,4 Dichlorophenoxy acetic acid, abscisic acid, and hydrogen peroxide induced resistance-related components against potato early blight (Alternaria solani, Sorauer). Ann Agric Sci 61(1):15-23

Nour El-Deen AH, Issa AA (2016) Nematicidal properties of some algal aqueous extracts against root-knot nematode, Meloidogyne incognita in vitro. Egypt J Agron 15(1):67-78

Paracer SM, Tarjan AC, Hodgson LM (1987) Effective use of marine algal products in the management of plant parasitic nematodes. J Nematol 19:194-200.

Punja ZK, Zhang Y (1993) Plant chitinases and their roles in resistance to fungal diseases. J Nematol 25(4):526-540

Radwan MA, Farrag SA, Abu-Elamayem MM, Ahmed NS ( 2012) Biological control of the root-knot nematode, Meloidogyne incognita on tomato using bioproducts of microbial origin. Appl Soil Ecol 56: 58-62

Rani IC, Veer A, Sanjutha S (2008) Analysis on biochemical basis of root knot nematode (Meloidogyne incognita) resistance in tomato (Lycopersicon esculentum Mill.). Res J Agric Biol Sci 4:866-870

Rosario JC, Josephine RM (2015) Mineral profile of edible algae Spirulina platensis. Int J Curr Microbiol App Sci 4(1):478-483

Saad MG, Ghareeb RY, Saeed AA (2019) The potential of endophytic fungi as biocontrol agents against the cotton leaf worm, Spodoptera littoralis (Boisd.) (Lepidoptera: Noctuidae). Egypt J Biol Pest Control 29:7

Santaniello A, Scartazza A, Gresta F, Loreti E, Biasone A, Di Tommaso D, Piaggesi A, Perata P (2017) Ascophyllum nodosum seaweed extract alleviates drought stress in Arabidopsis by affecting photosynthetic performance and related gene expression. Front Plant Sci 3(8):1362

Sharma IP, Sharma AK (2015) Effects of initial inoculums levels of Meloidogyne incognita $\mathrm{J}_{2}$ on development and growth of Tomato cV. PT-3 under control conditions. Afr J Microbiol Res 9(20):1376-1380

Shimizu Y (2003) Microalgal metabolites. Curr Opin Microbiol 6:236-243

Silva M, Vieira L, Almeida AP, Kijjoa A (2013) The marine macro algae of the genus U/va: chemistry, biological activities and potential applications. Oceanography 1:101

Taylor AL, Sasser JN (1978) Biology, identification and control of root-knot nematodes (Meloidogyne species). Coop. Publ, Dep. Plant Pathol North Carolina State Univ and US Agency Int Dev, Raleigh, p 111

Thompson B (2004) Five years of Irish trials on biostimulants: the conversion of a skeptic. USDA For ServProc 33:72-77

Torres MA, Dangl JL, Jones JDG (2002) Arabidopsis homologues Atrboh D and AtrbohF are required for accumulation of reactive oxygen intermediates in the plant defense response. Proc Natl Acad Sci U S A 99:517-522

Vernieri P, Borghesi E, Ferrante A, Magnani G (2005) Application of biostimulants in floating system for improving rocket quality. J Food Agric Environ 3:86-88

Wan JR, Zhang XC, Neece D, Ramonell KM, Clough S, Kim SY, Stacey G (2008) A Lys $M$ receptor-like kinase plays a critical role in chitin signaling and fungal resistance in Arabidopsis
Wu Y, Jenkins T, Blunden G, Whapham CA, Hankins SD (1997) The role of betaines in alkaline extracts of Ascophyllum nodosum in the reduction of Meloidogyne javanica and M. incognita infestations of tomato. Fundam Appl Nematol 20(2):99-102

Wuyts N, Swennen R, De Waele D (2006) Effects of plant phenylpropanoid pathway products and selected terpenoids and alkaloids on the behaviour of the plant-parasitic nematodes Radopholus similis, Pratylenchs penetrans and Meloidogyne incognita. Nematology 8:89-101

Youssef MMA, Ali MS (1998) Management of Meloidogyne incognita infecting cowpea by using some native blue green algae. Anz Schad Pflanz Unwelt 71:15-16

Zaki MJ, Amer-Zareen SA, Khan MQ (2005) Effect of seaweeds on the efficacy of Pasteuria penetrans in the control of root-knot nematode, Meloidogyne javanica in eggplant. Int J Phycol Phycochem 1:65-72

\section{Publisher's Note}

Springer Nature remains neutral with regard to jurisdictional claims in published maps and institutional affiliations.

\section{Submit your manuscript to a SpringerOpen ${ }^{\circ}$ journal and benefit from:}

- Convenient online submission

- Rigorous peer review

- Open access: articles freely available online

- High visibility within the field

- Retaining the copyright to your article

Submit your next manuscript at $>$ springeropen.com 